\title{
Dari Konflik ke Integrasi Sosial: Pelajaran dari Ambon-Maluku
}

\author{
From Conflict to Social Integration: A Lesson from Ambon-Maluku
}

\author{
SAIDIN ERNAS 1
}

\begin{abstract}
Post-conflict in Ambon-Maluku, indicated that eventhough people were segregated in the Islamic-Christian areas, butgradually the social integration has begun to occur naturally. The process of integration that occurred also gave new values that give hope to the future of peace. Using the theory of social integration adaptation from Parsonian structural-functional Classic paradigm, this study successfully formulated several important findings. First, social integration occurred in Ambon could run naturally through economic interaction, consensus on political balances and inclusive religious spirit. Second, the new social integration has created an important meaning that leads to a model of active harmony characterized by a process of social interaction that more active between different religions. Third, this study also reminds us that although there has been a proces sof positive social integration, people still need to be aware of the growth of radical religious ideologies and also strengthening politics identity in local politics that are dangerous to the development of peace.
\end{abstract}

Keywords: religious conflict, social integration, peace, Ambon-Maluku

Konflik yang melanda Ambon-Maluku sepanjang 1999-2003, merupakan salah satu tragedi kemanusiaan yang terbesar di Indonesia. Konflik dan rusuhan yang berlaku dalam kejadian keganasan kolektif dengan simbol-simbol agama yang kental telah menyebabkan kehancuran luar biasa. Baik dari segi jumlah korban jiwa, kerugian harta benda maupun kehancuran moral dan bebanan sosial keagamaan masyarakat Maluku yang kesannya masih terasa hingga kini termasuk pembelahan sosial (segregasi) antara komuniti Muslim dan Kristian. Tidak menghairankan apabila Azra (2000) pernah menyebut konflik Maluku sebagai konflik sosial yang paling dahsyat dalam sejarah Indonesia moden. Sungguh pun demikian, konflik agama yang demikian dahsyat akhirnya dapat dihentikan setelah melalui proses dialog yang panjang dan berliku. Dimulakan dengan Perjanjian Malino pada tahun 2002, kedua pihak yang bertikai akhirnya bersepakat untuk menghentikan konflik sebagai jalan untuk membangun perdamaian. Mereka berusaha untuk kembali hidup normal dan melupakaan tragedi besar yang telah menyebabkan mereka saling memusuhi selama beberapa tahun. Secara perlahan hubungan sosial antara masyarakat yang berbeza agama, etnik dan budaya kembali terjalin. Awalnya melalui aktiviti ekonomi, acara keagamaan dan interkasi sosial yang alamiah melalui ruang masyarakat.

Fenomena sosial mutakhir yang terjadi di Ambon, disebut sebagai tanda positif tentang perdamaian. Namun sejauh mana fenomena tersebut menjadi asas yang kukuh bagi bangunan harmoni dan perdamaian, tentu memerlukan kajian baru yang bersifat evaluatif. Kajian tentang integrasi sosial menjadi pintu masuk untuk menganalisis dan menilai proses-proses perubahan

\footnotetext{
${ }^{1}$ Saidin Ernas, Ph.D., lecturer at Institut Agama Islam Negeri Ambon, Jalan Dr. H. Tarmizi Taher - Kebun Cengkeh - Batu Merah Atas, Sirimau, Kota Ambon, MALUKU 97128, Indonesia. email: ernassaid@ gmail.com.
} 
yang telah terjadi setelah konflik, sebab konsep integrasi sosial masa kini bukan saja tentang usaha penyatuan masyarakat majmuk yang berbeza agama dan etnik dalam sebuah identiti bersama, atau asimilasi antara kelompok minoriti dengan kelompok dominan (Pranawati 2011). Tetapi lebih dari itu konsep integrasi sosial seperti dibicarakan beberapa ilmuwan sosial, hendaklah memperlihatkan bentuk-bentuk hubungan sosial yang otentik; saling mengakui (recognize), saling mempercayai (trust) dan memiliki kesetaraan (equal) (Varshney 2003). Demikian juga integrasi sosial hendaklah dilihat dalam konteks sejauhmana telah tumbuh moraliti baru yang menyokong harmoni dan perdamaian dalam masyarakat yang akan mengikat masyarat dalam sebuah sistem sosial yang seimbang (socilal equilibrium) (Parekh 2008).

Tulisan ini pada dasarnya adalah sebuah proses evaluasi kritis tentang dinamika perdamaian di kota Ambon ketika ini, terutama tentang usaha-usaha alamiah dari masyarakat untuk membangun relasi sosial yang semakin harmonis di tengah pembelahan sosial. Masih terdapat segregasi sosial, di mana pemukiman penduduk masih terbelah berdasarkan identitiidentiti keagamaan amtara Muslim dan Kristian. Fenomena ini menjadi momentum yang tepat untuk mengkaji perubahan-perubahan yang terjadi pasca konflik. Apakah telah terjadi proses integrasi yang otentik antara komuniti etnik dan agama di kota Ambon? Bagaimana bentuk dan proses integrasi yang terjadi, apakah memberi sumbangan kepada pengukuhan perdamaian atau masih terjadi segregasi sosial yang menunggu waktu untuk kembali meledak dalam suasa yang membahayakan.

\section{Perspektif Teori Integrasi Sosial dalam Pembangunan Perdamaian}

Secara umum teori utama yang dipilih sebagai grand theory dalam memahami fenomena integrasi sosial dan usaha membangun perdamaian di Ambon-Maluku adalah dengan menggunakan teori integrasi sosial (sosial integration). Dalam kajian sosiologi, teori integrasi sosial merupakan sebahagian daripada paradigma fungsionalisme struktural yang diperkenalkan oleh Talcot Parson (1927-1979). Paradigma ini mengandaikan bahawa pada dasarnya masyarakat berada dalam sebuah sistem sosial yang mengikat mereka dalam keseimbangan (ekuilibrium). Hal ini tercermin dari dua pengertian dasar integrasi sosial iaitu, pertama, pengendalian terhadap konflik dan penyimpangan sosial dalam suatu sistem sosial tertentu, dan kedua, menyatukan unsur-unsur tertentu dalam suatu masyarakat sehingga tercipta sebuah tertib sosial (Ritzer \& Goodman 2004). Proses ini ingin mengintegrasikan kelompok-kelompok sosial dalam masyarakat, dengan cara menghubungkan perbezaan-perbezaan yang ditimbulkan oleh faktorfaktor daerah, budaya, agama, kepentingan, kelas sosial dan sebagainya, dengan mengurangi ketidakseimbangan yang ditimbulkan oleh faktor-faktor tersebut.

Selama ini kajian tentang integrasi sosial sering dipengaruhi oleh wacana kekuasaan tentang penyatuan dalam sebuah kekuatan identiti untuk mengatasi perbezaan. Suatu tafsir sosial yang menonjolkan adanya penundukan terhadap kekuatan-kekuatan minoriti untuk tunduk dan menyatu di bawah kuasa identiti golongan majoriti. Maka sebagai kelanjutan dari cara pandang yang demikian itu, diketengahkan konsep asimilasi, di mana identiti dan kebudayaan pihak minoriti lebih diharapkan menyatu dengan identiti budaya golongan majoriti.

Selama ini kajian tentang integrasi sosial sering dipengaruhi oleh wacana kekuasaan tentang penyatuan dalam sebuah kekuatan identiti untuk mengatasi perbezaan. Suatu tafsir sosial yang menonjolkan adanya penundukan terhadap kekuatan-kekuatan minoriti untuk tunduk dan menyatu di bawah kuasa identiti golongan majoriti. Maka sebagai kelanjutan dari cara pandang yang demikian itu, diketengahkan konsep asimilasi, di mana identiti dan kebudayaan pihak minoriti lebih diharapkan menyatu dengan identiti budaya golongan majoriti. Dalam kajiannya terhadap integrasi nasional, Nazaruddin (1996) menyebutkan bahwa integrasi sosial adalah bahagian dari konsep integrasi nasional yang pada dasarnya mencakup dua persoalan mendasar. Pertama, bagaimana membuat rakyat tunduk dan patuh pada tuntutan dan kepentingan bersama iaitu berbangsa dan bernegara. Kedua, bagaimana meningkatkan 
konsensus normatif yang mengatur tingkah laku positif masyarakat atau individu-individu yang ada di dalamnya. Pandangan Nazaruddin, mewakili banyak ilmuwan politik pada zamannya yang memandang negara sebagai satu-satunya entiti sosial politik yang harus dipelihara kewujudannya, meskipun dalam proses tersebut, tidak dapat dielakkan dengan pengabaian terhadap keragaman dan perbezaan yang telah menjadi fakta sosial di Indonesia.

Sejak terjadinya gerakan reformasi 1998 di Indonesia, yang diwarnai dengan demokrasi dan demokratisasi yang mendorong wacana keterbukaan, maka banyak ilmuwan mengkritik konsep integrasi sebagai sebahagian dari wacana kekuasaan yang cenderung hegemonik itu. Banyak ilmuwan dan pengkaji memandang konsep integrasi sosial sebagai konsep ilmu sosial yang telah kehilangan konteksnya di tengah tuntutan demokrasi dan penghormatan terhadap perbezaan. Maka setiap kajian yang mempromosikan integrasi sosial dianggap sebagai aktiviti teoritis yang tidak menarik dan pro status quo. Padahal menurut penulis, yang diperlukan oleh ilmuwan sosial adalah melepaskan sebuah konsep keilmuan dari tafsir kekuasaan yang selama ini menghegemoninya. Sebagaimana ditegaskan oleh sosiologis Nugroho (1999,) para ilmuan sosial dewasa ini memerlukan perimbangan wacana publik secara seimbang dengan cara ikut serta dan terlibat dalam diskursus tentang keragaman, tanpa ada pemaksaan dari negara terhadap masyarakat sivil.

Dalam nafas yang sama, tulisan ini mencuba melihat kembali konsep integrasi sosial dalam alam pemikiran demokratis, yang melihat perbezaan sebagai realiti politik yang mesti dikelola dengan cara-cara yang demokratik pula. Pandangan demokratis terhadap konsep integrasi sosial menekankan pentingnya hubungan yang setara dan saling menguntungkan. Biku Parekh (2008: 84-87) menjelaskan bahwa proses integrasi sosial dalam sebuah masyarakat demokratis mensyaratkan tiga hal. Pertama, adanya kesepakatan dari sebagian besar anggotanya terhadap nilai-nilai sosial tertentu yang bersifat fundamental dan penting (moral contract). Kedua, masyarakat terhimpun dalam berbagai unit sosial yang saling mengawasi dalam aspekaspek sosial yang berpotensi. Hal ini untuk menjaga terjadinya dominasi dan penguasaan dari kelompok majority ke atas minoriti. Ketiga, terjadi saling ketergantungan di antara kelompokkelompok sosial yang terhimpun di dalam suatu masyarakat untuk memnuhi keperluan ekonomi dan sosial secara menyeluruh.

Modal utama lahirnya integrasi sosial dalam masyarakat demokratik adalah adanya sebuah situasi di mana masyarakat dapat saling berkomunikasi dan beriteraksi secara egaliter, penuh kepercayaan (trust) dan saling memerlukan. Menurut Varsney (2003), situasi seperti itu terjadi melalui civic engagement, baik melalui interaksi yang digerakkan kelompok civil society (organize civic network), mahupun interaksi yang terjadi secara alamiah melalui ruang publik yang egaliter (everyday civic network). Kedua proses tersebut melahirkan kepercayaan yang menyebabkan kelompok-kelompok yang berbeza dalam masyarakat tidak akan terlibat dalam kegiatan kekerasan kepada yang lain. Integrasi sosial juga memerlukan pengiktirafan (recognition) terhadap wujudnya perbezaan dan hak bagi perbezaan itu untuk hidup dalam masyarakat. Dengan adanya pengakuan seperti itu, maka lahir sikap yang toleran terhadap perbezaan. Syarat penting lainnya seperti disebut Parekh (2008) adalah a moral contract semacam nilai-nilai bersama yang mengikat masyarakat dalam keseimbangan.

Pandangan baru tentang integrasi sosial dalam sebuah masyarakat demokratik, tentu tidak menafikan adanya konflik sebagai sebahagian yang tidak memisahkan dari fenomena sosial dan perubahan. Sebab konflik, seperti yang dijelaskan Ralf Dahrendrof adalah fenomena sosial yang selalu hadir (inherent omni presence) dalam setiap masyarakat manusia. Masyarakat manusia di manapun mereka berada akan senantiasa menghadapi kemungkinan terjadinya konflik, termasuk juga di Ambon-Maluku. Namun potensi konfliktual tidak mesti dihadapi dengan cara-cara kekuasaan yang hegemonik, masyarakat dan negara perlu mengelola berbagai potensi konflik yang ada dengan cara-cara yang diterima oleh semua pihak (Rauf 2000: 15). 
Kes perdamaian di Kota Ambon-Maluku yang diangkat dalam tulisan ini menunjukkan bahawa meskipun konflik Maluku telah berlalu tetapi masyarakat memerlukan norma dan konsensus bersama untuk mengelola perbezaan yang menjadi realiti sosial di antara mereka. Jika masyarakat mengambil pengalaman dan pelajaran berharga dari konflik, maka mereka membangun sebuah proses integrasi sosial di atas asas nilai-nilai kebijaksanan baru yang akan mengikat mereka dalam kebersamaan. Nilai-nilai kebersamaan yang mempromosikan harmoni dan perdamaian, apapun bentuknya akan menjadi habitus yang positif dalam masyarakat (Abdullah 2008). Habitus itu akan menjadi struktur mental atau kognitif yang dengannya masyarakat Ambon akan berjuang memulihkan hubungan sosial yang terkoyak di antara mereka.

\section{Fenomena Konflik dan Segerasi Sosial di Kota Ambon}

Konflik yang terjadi di Ambon sejak tahun 1999 hingga 2004, telah mengakibatkan kehancuran yang luar biasa. Selain jumlah korban meninggal dunia dan luka-luka, berbagai fasiliti awam dan rumah-rumah juga hancur atau hangus terbakar. Di sisi lain, dampak konflik juga mengakibatkan masyarakat Maluku terpecah secara ekstrim menjadi dua komuniti, iaitu komuniti Muslim dan komuniti Kristian. Masyarakat yang tinggal dan menetap di suatu perkampungan yang terdiri dari beragam suku, ras dan agama mengungsi dan terpisah serta berkumpul atau menyatu dengan komuniti masing-masing.

Setelah pelaksanaan Perjanjian Malino Tahun 2002, kota Ambon secara perlahan mulai kondusif, ditandai dengan menurunnya intensiti konflik, pemusnahan senjata, pembangunan fasiliti awam dan pulangnya para pelarian yang selama ini berlindung di pelbagai tempat (baik di kota Ambon maupun wilayah lainnya di luar Maluku). Namun para pelarian menghadapi kenyataan traumatik dan rasa takut untuk kembali menempati rumah dan bertemu tentangga lama yang berbeda agama. Maka umumnya para pengungsi memilih pemukiman baru dengan agama yang homogen (Abdullah 2008). Pelarian Kristian kembali ke pemukiman yang majoriti Kristian, demikian juga pengungsi Muslim yang mulai membangun rumahnya di pemukimanpemukiman yang serratus peratus beragama Islam. Sebahagian pengungsi berinisiatif melakukan barter tempat tinggal dengan warga yang berbeza agama untuk memperoleh rumah baru di pemukiman yang seagama. Masyarakat Muslim umumnya menghuni wilayah di Waihaong, Silale dan yang tersebar di desa Batu Merah yang penduduknya semakin padat. Beberapa rumah terpaksa dibangun di lereng-lereng gunung dan bukit yang membahayakan keselamatan dan merosak lingkungan dan kelestarian alam. Desa Batu Merah yang tidak luas terpaksa menerima ribuan pengungsi yang mencari tempat tinggal baru di desa Muslim tersebut. Sedangkan masyarakat Kristian memilih tinggal di Kecamatan Nusaniwe, seperti Latuhalat, Amahusu, Kudamati, Batu Gantung, Wainitu dan Mangga Dua. Wilayah Kristian juga mencakupi Karang Panjang, Ahuru dan beberapa tempat lainnya di wilayah Galala hingga Paso di Kecamatan Baguala. Secara fakta, wilayah Kristian masih tampak lebih luas dibandingkan wilayah yang didiami oleh komuniti Muslim, namun wilayah Kristian juga merupakan pemukiman-pemukiman yang padat.

Segregasi sosial yang tercipta secara sosiologi memang sangat merisaukan. Pemukiman yang dibangun di atas identiti kelompok yang homogen dan eksklusif tentu secara sosiologi tidak sihat dan mudah menimbulkan kecurigaan-kecurigaan dan masalah sosial hingga menyebabkan konflik. Sebabnya adalah tidak ada kelompok lain yang menjadi katalisator terhadap isu-isu konflik dan pertentangan yang muncul dalam masyarakat. Padahal diharapkan dalam lingkungan warga yang memeluk agama yang beragam, justru terjadi integrasi sosial dan peluang untuk saling melindungi. Blau \& Schwartz (1984) menyebut pentingnya situasi yang heterogen untuk memperkuat kesetiaan berganda dalam hidup bermasyarakat. Maksudnya, adalah seseorang yang beragama selain berafiliasi dengan tetangga yang seagama juga menjaga hubungan dengan tetangga lain yang mungkin memiliki agama yang berbeza. Hal ini sebagai kesan dalam kependudukan yang sama. Inilah yang disebut sebagai "loyalitas ganda", di mana semakin banyak 
kesetiaan sosial pada banyak kepentingan maka membuat seseorang memiliki toleransi dan menjaga hubungan yang baik kepada semua orang. Melalui hubungan yang heterogen masyarakat saling menjaga dan melindungi. Namun pandangan Petter Blau, nampaknya boleh diperbetulkan apabila mengamati fenomena konflik Ambon, di mana di antara tentangga terjadi saling serang dan membunuh. Mereka seakan tidak memiliki kesetiaan pada tentangga yang selama ini telah hidup bertentangan selama bertahun-tahun.

\section{Bentuk-Bentuk Integrasi Sosial di Kota Ambon}

Setelah konflik dan kekerasan secara perlahan mulai mereda, masyarakat kota Ambon kembali berusaha membangun kehidupan sosialnya, awalnya hubungan sosial agak sukar, sebab perasaan curiga dan dendam masih cukup kuat di dalam masyarakat. Namun dapat dilihat bahawa masyarakat mulai belajar bagaimana mengelola kehidupan sosial yang diwarnai beragam perbezaan dengan cara-cara yang tidak normal. Abnormalitas yang dimaksudkan adalah ketika masyarakat dipaksa untuk menerima fakta bahawa kehidupan kota Ambon telah mengalami segregasi sosial yang ekstrim dan menjadi wajah baru kota kecil yang padat ini. Apalagi mengecilnya lahan pemukiman telah menyukarkan pemerintah untuk mendorong pembangunan unit-unit pemukiman baru yang menjadi "oase" tempat tinggal bersama bagi pelbagai kelompok, terutama kelompok agama yang berbeza-beza. Memang di beberapa tempat seperti di Poka dan Wayame pemukiman warga masih cukup berwarna, tetapi secara keseluruhan Ambon adalah sebuah kota yang terbelah.

Akan tetapi fenomena yang terjadi di Ambon mengesahkan kebenaran teori struktural fungsional dari Parson (1927-1929) yang meyakini bahawa masyarakat merupakan sebuah sistem yang terdiri dari unit-unit sosial beragam, yang secara alamiah dan sistematik akan mengalami proses integrasi kembali (Ritzer 1992 \& Douglas). Akan terbentuk sebuah sistem sosial yang mengikat masyarakat dalam keseimbangan sosial (social equilibrium). Manusia adalah mahluk sosial yang selalu memerlukan kehidupan bersama, sebab itu para ahli teori struktural fungsional percaya bahawa manusia selalu berusaha menemukan cara untuk membangun kehidupan bersama yang lebih baik, meskipun dalam proses tersebut terjadi konflik dan pertentangan. Sebab sesuai dengan kudratnya, manusia memerlukan situasi tertentu untuk memenuhi keperluan ekonomi, politik dan kebudayaannya. Konflik dan damai akhirnya lahir sebagai sebuah kontradiksi tetapi saling melengkapi, dan inilah fakta yang terjadi di Kota Ambon pasca konflik Maluku.

Pertama, integrasi sosial yang secara alamiah untuk memanfaatkan aktiviti ekonomi di pasar-pasar lokal. Sebagaimana diketahui, situasi yang sangat nyata pasca konflik Maluku adalah masyarakat mengalami kondisi ekonomi yang memprihatinkan. Di beberapa tempat masyarakat mengalami kesukaran untuk memperoleh bahan keperluan harian, sebab distribusinya terhambat oleh segregasi sosial dan pemukiman yang saling berjarak. Masing-masing kelompok membangun kehidupan sendiri, memiliki aktiviti ekonomi sendiri, memiliki pasar sendiri dan seterusnya. Dalam kondisi seperti ini terdapat kelompok-kelompok masyarakat pada kedua komuniti yang secara sembunyi-sembunyi dan penuh risiko saling berkomunikasi dan mengadakan transaksi barangan keperluan untuk dijual kepada masyarakat di lingkungannya. Kelompok dengan kepentingan ekonomi ini berinisiatif untuk membuka kebekuan akibat pertikaian dan hidup yang tersegregasi, melalui komunikasi dan pertukaran barang dagangan di antara para pedagang. Pasar Mardika dan Batu Merah yang secara geofrafi terletak tepat di antara komuniti Muslim dan Kristian di Kota Ambon berperanan sebagai media yang mempertemukan masyarakat. Mereka yang berasal dari komuniti Muslim mahupun Kristian menjual barang dagangannya di sana. Lambat laun pasar Mardika yang pernah dibumihanguskan selama konflik kembali aktif dan menjadi ruang publik yang pertama untuk saling bertemu. Pedagang Bugis, Makassar dan lainnya yang selama ini telah pergi meninggalkan Ambon kembali ke pasar dan membangun kembali kedai-kedai dan kiosk-kiosk mereka yang telah musnah. 
Fenomena di Ambon menunjukkan bahwa pasar adalah tempat yang mempunyai unsurunsur sosial, ekonomi, kebudayaan, politik dan lain-lainnya. Aktiviti di pasar tidak hanya memiliki nilai-nilai ekonomi semata (tempat pembeli dan penjual saling bertemu untuk mengadakan tukar-menukar wang dan barang), tetapi juga memiliki dimensi sosial yang saling berhubungan satu sama lain dalam kehidupan masyarakat. Peranan pasar berubah menjadi media integrasi sosial, mempertemukan berbagai kelompok yang beragam yang awalnya membangun hubungan kerana keperluan ekonomi. Namun melalui kontak tersebut jalinan komunikasi yang terputus kembali bersambung. Kegiatan ekonomi di pasar menjadi 'salah satu' factor melahirkan gerakan rekonsiliasi di Ambon, yang dilakukan tanpa direkayasa, alamiah dan berasaskan kepada inspirasi masyarakat bawah, sangat inklusif dan sekaligus menjadi bukti bahawa ekonomi tidak hanya menjadi pemicu konflik tetapi juga menjadi hujung tombak penyatu kedua komuniti yang sementara bertikai (Kristian adan Muslim).

Kedua, upaya memanfaatkan acara keagamaan sebagai media integrasi sosial. Tanpa disedari ritual dan ucara keagamaan adalah peristiwa yang sarat dengan ekspresi simbolik yang penuh makna. Mengutip Abdullah (2006), kegiatan acara keagamaan dan ritual adalah momentum untuk terus mempertahankan nilai-nilai dan mecetuskan nilai-nilai keagamaan sebagai media komunikasi dan integrasi komuniti. Melalui acara keagaman masyarakat mampu membangun hubungan dan integrasi sosial untuk meningkatkan keseimbangan sosial. Perkembangan pasca konflik Maluku menunjukkan bahawa masyarakat kota Ambon memnafaatkan upacara keagamaan sebagai media untuk membentuk integrasi sosial dan melahirkan kebersamaan di antara mereka.

Ada dua acara keagamaan yang digunakan sebagai momentum untuk melakukan integrasi dan media kerukunan, yakni Musabaqah Tilawatul Quran (MTQ) Peringkat Nasional 2012 dan Pesta Paduan Suara Gerejawi (Pesparawi) Nasional 2015. Pada acara MTQ Nasional tahun 2012 masyarakat kota Ambon yang berbeza agama mulai mencuba membangun kebersamaan melalui keterlibatan aktif dalam kegiatan tersebut. Meskipun MTQ adalah acara keagamaan umat Islam, namun secara jelas dilihat warga Kristian dan Katolik di Kota Ambon juga terlibat dalam kegiatan tersebut. Bentuk-bentuk keterlibatan yang boleh dicatat adalah partisipasi sebagai peserta paduan suara untuk menyanyikan lagu dan mars MTQ, menjadi panitia dalam berbagai fungsi, dan berpartisipasi menyediakan tempat penyelenggaraan beberapa sistem pemarkahan MTQ. Bahkan sejumlah warga Kristian menawarkan rumahnya sebagai tempat menginap bagi para peserta MTQ dari berbagai daerah. Sementara itu di berbagai jalan-jalan utama hingga lorong-lorong sempit di Kota Ambon, warga Kristiane memasang berbagai spanduk yang memuat pernyataan mendukung MTQ di Kota Ambon. Beberapa peserta yang berasal dari berbagai daerah menyatakan ketakjubannya terhadap sambutan masyarakat Kristian kota Ambon dalam penyelenggaraan MTQ tersebut.

Sama halnya dengan MTQ, pada acara Pesparawi Nasional 2015, yang merupakan pertandingan lagu-lagu gerejawi umat Kristian se-Indonesia, juga mendapat sambutan hangat dari warga Muslim di Kota Ambon. Masyarakat Muslim Batu Merah, menyediakan rumah-rumah mereka sebagai tempat penginapan bagi kontingen pesparawi yang berasal dari berbagai provinsi. Di masjid Batu Merah masyarakat membunyikan selawat dan nyanyian keagamaan menyambut kontingen Pesparawi dari berbagai provinsi yang melalui desa Batu Merah. Mereka membentang kain putih dan meminta Kontingen Pesparawi untuk turun dari kenderaan berjalan kaki bersama warga melintas perkampungan Batu Merah sebagai tanda wujud persaudaraan. Penulis juga mencatat berbagai kegiatan bersama dalam menjaga rumah ibadah pada hari-hari besar keagamaan seperti Hari Lebaran dan Hari Natal. Pada kegiatan Hari Raya Idul Fitri, sejumlah pemuda dari Batu Gantung yang Kristian, biasanya hadir sebagai sukarelawan yang membantu menjaga kegiatan Solat Idul Fitri supaya dapat dilaksanakan dengan aman. Demikian halnya pada pelaksanaan Natal, juga banyak pemuda dari Batu Merah, Waihaong dan Silale yang turut menjaga pelaksanaan ibadah Natal di sejumlah gereja di Kota Ambon, salah satu di antaranya adalah di Gereja Silo. Apa yang terjadi di Ambon menunjukkan usaha menjadikan 
moment keagamaan dan ritual sebagai media untuk membangun integrasi dan harmoni sosial. Acara keagamaan dipilih kerana secara simbolik menjadi menjadi media yang membawa pesanan serta simbol yang mengintegrasikan kelompok-kelompok masyarakat yang berbeza agama dalam kesedaran-kesedaran religio-culture.

Ketiga, pemanfaatan ruang-ruang publik sebagai arena integrasi sosial. Dalam konteks kehidupan di kota Ambon maka ruang publik yang berperanan dalam mendorong komunikasi dan integrasi antara warga masyarakat adalah pusat-pusat aktiviti ekonomi (pasar), pejabat kerajaan, sekolah dan kedai kopi yang tumbuh semarak pasca konflik Maluku. Pejabat-pejabat pemerintahan memiliki peranan yang sangat penting untuk mempertemukan masyarakat dari berbagai latar belakang. Para pegawai "dipaksa" oleh sistem yang berlaku di pejabat untuk saling bekerjasama, manakala sekolah pula telah menjadi ruang publik bagi semua siswa dengan berbagai latar belakang. Meskipun sama dengan pejabat, selama konflik ruang publik sekolah juga tersegregasi berdasarkan agama. Namun saat ini mulai terjadi perubahan, terutama untuk sekolah-sekolah yang berada di wilayah perbatasan Muslim dan Kristian, seperti di SMA 3 Kota Ambon. Tulisan Latuconsina (2013) menyebutkan bahawa sekolah yang semakin inklusif merupakan tempat persemaian benih-benih toleran di masa depan. Pelajar dari berbagai latar belakang, belajar untuk saling mengenal identiti keagamaan rakan masing-masing yang berbeza agama dan keyakinan, sehingga diharapkan dapat membentuk karakter dan watak yang inklusif di kalangan generasi muda. Adapun ruang publik yang terakhir adalah warung-warung kopi yang tumbuh subur setelah berhentinya konflik Maluku -di sepanjang Kota Ambon ditemui warung-warung kopi tersebut yang umumnya dipadati pengunjung, perempuan mahupun lakilaki, baik di pagi, siang, maupun lewat petang. Beberapa Warung kopi terkenal adalah Warung Kopi Balabu, Warung Kopi Lela, Warung Kopi Hatukau, Warung Kopi Joas dan Warung Kopi Sibusibu di Jalan Said Parintah. Warung kopi telah menjadi ruang publik yang mempertemukan masyarakat dari berbagai kelompok identiti yang berbeza. Suasana warung kopi yang cair, informal, dan penuh gurauan membangun keakraban antar pengunjung baik yang sudah saling kenal mengenal sebelumnya, ataupun orang baru. Perbincangan dan hubungan sosial yang terjadi di warung kopi mungkin tidak akan menyelesaikan secara langsung masalah-masalah yang muncul di masyarakat, tetapi pertemuan antara warga yang berbeza latar belakang di warung kopi memungkinkan komunikasi saling tukar perspektif dan pengetahuan. Kecurigaan dan berbagai bentuk informasi negatif lain dapat dikawal dan diperjelaskan melalui perbincangan di warung kopi. Khabar angin kerap menjadi pencetus konflik dapat diperjelaskan atau meminjam istilah dalam literatur kajian perdamaian "dibunuh" oleh proses saling bertukar pengetahuan sehingga tidak dapat dengan mudah digunakan untuk mobilisasi konflik.

Ruang publik yang egaliter akan menjadi "jambatan" hubungan baik antara agama dan etnik. Merujuk pada teori Varshney (2003) tentang modal sosial (social capital), pola hubungan di ruang publik yang egaliter akan menciptakan pola hubungan yang tidak formal dalam kehidupan sehari-hari (everyday forms of engagement). Menurutnya lagi, pola hubungan yang bersifat informal memiliki daya tahan yang lebih kuat (sturdier) dalam menghapus potensi konflik, bersifat alami dan bebas dari kepentingan politik yang kerap terjadi dalam organisasi yang bersifat formal. Akan tetapi, tidak bererti pola hubungan yang bersifat formal (association forms of engagement) seperti di pejabat dan sekolah tidak penting. Kedua jenis pola hubungan ini dapat berperanan penting dalam mencegah polarisasi berasaskan identiti yang berpotensi dimanfaatkan untuk memobilisasi konflik.

Keempat, konsensus tentang politik keseimbangan yang diikuti dengan upaya menetapkan sumber daya politik untuk mememenuhi semua kepentingan identiti. Hal ini menjadi penting sebab selama konflik, isu tentang keseimbangan jawatan-jawatan penting di birokrasi daerah menjadi hal yang terus menerus dibicarakan. Bahkan menjadi salah satu tema yang diperdebatkan secara sengit dalam Perjanjian Malino 2002 (Saidin 2012). Selain soal birokrasi lokal, keseimbangan dalam pengelolaan pendidikan di Universitas Pattimura juga dikritik oleh sejumlah tokoh Islam sebab dianggap hanya dikuasai oleh komuniti Kristian. Dalam 
perkembangan selanjutnya, konsep keseimbangan ini meskipun tidak diatur secara formal dalam peraturan yang ada di Maluku, namun menjadi kesedaran politik dan konsensus politik dalam praktik politik lokal dan pemerintahan di Maluku.

Oleh sebab itu, konfigurasi kepemimpinan politik selalu menjadi simbol akomodasi politik yang seimbang. Dalam pemilihan Gubernur Maluku pasca konflik, Brigader Jenderal (Purn) Karel Albert Ralahalu yang beragama Kristian berganding dengan Muhammad Latuconsina (Muslim) dan kemudian memenangkan pilkada. Pada period kedua, Karel berganding dengan Said Assegaf sebagai pasangan wakilnya dan berjaya sebagai pemenang. Pada tahap pemerintahan Kota Ambon, juga diamalkan keseimbangan tersebut. Jopy Papilaya berjaya dilantik sebagai Walikota berganding dengan Syarid Haldler dan pada tempoh berikutnya ia berganding dengan Olivia Latuconsina. Ketika ini Walikota Ambon period 2011-2016 dipegang oleh Richad Louhanapesy bersama Syam Latuconsina sebagai wakil Walikota. Hampir semua pasangan calon yang terlibat dalam Pilkada Gubernur ataupun Walikota tetap berganding dengan pasangan yang berlainan agama, Muslim-Kristian. Pada peringkat birokrasi tempatan, juga terjadi konsolidasi politik keseimbangan tersebut. Para pegawai diangkat berdasarkan kesimbangan agama, demikian juga dalam pembangunan. Sebagaimana tergambarkan dalam beberapa program pembangunan daerah yang dilaksanakan dengan mengambil pendekatan keseimbangan. Contohnya, pembangunan Islamic Center diikuti dengan pembangunan Kristiani Center dan menyusul juga Katolik Center dan lainnya. Pada satu tahun terakhir, pemerintah membiayai sejumlah imam Masjid untuk melaksanakan ibadah umrah yang dibiayai sepenuhnya oleh pemerintah daerah provinsi. Bersamaan dengan itu pemerintah juga membiayai sejumlah pendeta dan pastor untuk mengikuti wisata rohani ke Israel.

Pemerintah memberikan sumber ekonomi dan politik secara merata terhadap semua kekuatan politik untuk menghindari kecemburuan dan perasaan diperlakukan secara tidak adil. Contoh politik "bagi-bagi" jabatan ini juga dapat dilihat dari perspektif politik representasi yang secara tidak langsung dilaksanakan sebagai sebahagian integral dalam proses rekonsialiasi perdamaian. Dalam hal ini, representasi diertikan sebagai ekspresi kesetaraan posisi dalam relasi masyarakat yang heterogenistik. Demokrasi sendiri yang acapkali dimaknai sebagai suara golongan majoriti, sering membataskan suara minoriti yang selama ini diandaikan mengalah pada paradigma kepentingan publik (commons interest) tersebut. Maka salah satu ajudikasi yang dilakukan dalam representasi sebagai resolusi konflik di Maluku dan Ambon adalah menciptakan perimbangan komposisi jawatan birokrasi di antara lintas agama ataupun etnik.

\section{Tumbuhnya Semangat Inklusif dalam Integrasi Sosial Baru}

Konflik Ambon memperlihatkan dinamika di mana sistem sosial yang terbentuk pasca konflik cenderung mencari pola baru hubungan antara masyarakat. Perlahan tapi pasti, masyarakat Ambon (Muslim dan Kristian) cuba menemukan bentuk-bentuk baru kesedaran tentang perdamaian. Kesedaran itu memunculkan praktik-raktik sosial baru yang lebih terbuka dan inklusif, bahkan dengan energi yang lebih kuat. Fenomena ini disebut sebagai inklusif energetik yang menjadi model integrasi sosial dalam dinamika sosial di kota Ambon

Pertama, menguatnya semangat inklusif yang energetik dalam praktik kerukunan aktif. Secara keseluruhan, dikatakan bahawa nilai-nilai dari pemahaman keagamaan yang inklusif sedang tumbuh dan berkembang dalam masyarakat beragama di Kota Ambon, terutama di kalangan para pemimpin agama yang menyedari erti penting menumbuhkan nilai-nilai inklusif dalam mendukung perdamaian. Bahkan secara nyata nilai-nilai inklusif tersebut telah melahirkan model baru kerukunan beragama yang sangat aktif. Masyarakat bukan saja mengakui adanya perbezaan dalam masyarakat, namun secara aktif berupaya untuk saling belajar dan meningkatkan solidariti bersama dalam kehidupan.

Penggunaan istilah kerukunan aktif dalam tulisan ini untuk membezakan dengan wacana umum kerukunan beragama yang selama ini digunakan oleh negara. Misalnya dalam wacana 
regim Orde Baru, namum dalam keyataannya konsep ini terkesan pasif dan hegemonik. Kerukunan difahami hanya sebagai tidak mengganggu dan mencampuri urusan orang lain yang berbeza agama dan budaya. Sehingga selama era Orde Baru, konsep kerukunan dibatasi dengan kebijakan yang terkesan refresif. Dalam kebijakan SARA misalnya, demi kerukunan, orang ramai dilarang membicarakan hal-hal yang berkaitan perbezaan. Ini jelas melahirkan sikap tertutup terhadap perbezaan meski pada lahirnya tercipta kerukunan di permukaan. Beberapa sosiologis melihat kerukunan model Orde Baru adalah kerukunan yang pasif. Di mana orang hanya tahu ada keyakinan dan padangan politik lain yang berbzda dengan keyakinan dan pandangan politiknya, namun secara nyata ia tidak berusaha mengenal perbezaan-perbezaan tersebut, sebab dianggap akan menggangu kestabilan sosial.

Sementara itu, dalam konsepsi kerukunan aktif bukan saja tercipta toleransi sebagimana telah dibincangkan, tetapi juga muncul upaya-upaya aktif untuk saling berdialog dan meningkatkan saling pengertian. Kerukunan dibangun di atas kesedaran, pengetahuan dan kepercayaan yang dalam terhadap mereka yang berbeza. Dalam kerukunan aktif konsep dialog yang egaliter dan inklusif sangat menonjol, kerana orang didorong untuk membicarakan perbezaan sebagai usaha untuk belajar dan mengenal perbezaan, meski setajam apapun perbezaan yang ada. Maka kewujudan dialog bertujuan untuk memahami pandangan sesuai dengan konstruksi pemilik pandangan, bukan dari rekonstruksi kita sendiri. Dalam konteks ini istilah dialog antara agama menjadi sangat penting dalam bangunan toleransi, lebih dari sekadar kerukunan yang pasif.

Konteks kehidupan antara agama di Ambon, memperlihatkan bahwa nilai-nilai kerukunan yang berkembang aktif, ditandai dengan semakin semaraknya lembaga-lembaga keagamaan yang melakukan dialog-dialog lintas agama, khususnya di kalangan gereja Protestan Maluku, yang secara resmi telah menjadikan konsep dialog antara agama sebagai sebahagian dari pelayanan keagamaan. Kurikulum pendidikan dan pelatihan untuk para pendeta Kristian di Maluku, mulai menawarkan kajian intensif tentang dialog antara agama, antara Islam dan Kristian, bukan lagi kajian perbandingan agama semata-mata.

Kekuatan civil society yang tumbuh subur pasca konflik, juga tampil sebagai kekuatan yang mengukuhkan model kerukunan yang aktif tersebut, sebagaimana yang diperlihatkan oleh sejumlah teologi dan aktiviti yang tergabung dalam lembaga EL-AI-EM. Sejak tahun 2005 sejumlah aktiviti lembaga tersebut fokus dalam menganjurkan dialog-dialog publik berkaitan dengan berbagai permasalahan sosial, termasuk isu-isu teologi keagamaan. Dialog publik digunakan untuk membangun persepsi bersama terhadap beberapa isu kontemporari yang berkitar dalam wacana publik sehari-hari di kota Ambon. Selain itu dilakukan pula berbagai pertemuan terbatas lintas iman, untuk mencermati dan memetakan perkembangan situasi keamanan dari masa ke semasa, kemudian disampaikan kepada beberapa stake holders, yang memiliki jaringan dan pengaruh di masyarakat. Sebagaimana juga telah digambarkan, peranan serta masyarakat dari berbagai kelompok yang berbeza agama dalam acara keagamaan seperti MTQ, Pesparawi dan partisipasi dalam mengamankan rumah ibadah pada saat Hari Raya dan Natal adalah bentuk nyata dari kerukunan yang aktif tersebut. Masyarakat bukan saja mahu menghormati perbezaan, tetapi juga terlibat dalam tindakan nyata untuk melembagakan nilainilai kerukunan sebagai jalan membangun kehidupan bersama yang toleran.

Kerukunan aktif adalah semangat baru keberagamaan yang sedang berkembang di Ambon. Perkembangannya tidak mudah kerana kadang-kadang berhadapan dengan kritikan dan gugatan dari fahaman keagamaan konservatif. Di masa depan semangat kerukunan aktif akan menjadi nilai-nilai baru dalam semangat keberagamaan warga kota Ambon. Di sini boleh dilihat bahawa secara tidak langsung, konflik telah mendorong sebuah model keagamaan baru yang jauh lebih progresif dalam menyikapi perbezaan keyakinan dan kepercayaan.

Kedua, Semangat inklusif energetik dalam gagasan pluralisme dan multikulturalisme sebagai wujud kesedaran baru untuk membangun perdamaian di Kota Ambon. Beberapa institusi lokal di Ambon, seperti LSM, lembaga keagamaan dan perguruan tinggi berusaha 
menginternalisasi wacana pluralisme dan multikulturalisme dalam perikehidupan masyarakat lokal. Mereka menjadikannya sebagai tema utama, slogan agama atau perbincangan kebudayaan di ruang-ruang publik dan tentu saja di dunia akademik. Bahkan ada universiti yang menjadikannya secara resmi sebagai salah satu visi dan misi yang diimplementasikan dalam program akademik ataupun sosial budaya.

Isu pluralisme digunakan secara demonstratif oleh Gereja Protestan Malaku (GPM) dalam membingkai dialog-dialog keagamaan. Pluralisme biasanya digandingkan dengan praktikpraktik tentang kearifan lokal seperti Pela dan Gandong. Ketika merayakan ulang tahunnya yang ke-80 pada tahun 2015 ini, GPM membawa tema pluralisme yang diserapkan dalam naskahnaskah gereja hingga menjadi slogan publik. Isu pluralisme dianggap sebagai ekstrak dari pengalaman konflik yang panjang dan revitalisasi atas kearifan lokal sebagai media dialog dalam keragaman. Lis Marantika dari GPM Maluku menyebutkan bahawa pluralisme yang diangkat oleh Gereja Protestan Maluku seiring dengan semangat keagamaaan orang bersaudara dan pesanpesan moral dalam kita suci. Apa yang disebut Lis tentu memperolehi kebenaran empirik jika melihat keseluruhan proses tranformasi gereja Protestan Maluku pasca konflik. GPM terus melakukan sosialisasi untuk mendorong pemahaman tentang pentingnya sikap pluralis dalam praktik keberagamaan di Maluku. Bagi para pemimpin GPM, masyarakat Ambon dan Maluku dapat menjadikan pluralisme sebagai pendekatan baru untuk melekatkan diri dalam keberagaman. Proses tersebut dilakukan melalui dialog yang egaliter, dan revitalisasi atas nilainilai kearifan lokal. Selain institusi gereja, Universitas Kristen Maluku (UKIM) juga mengisytiharkan diri sebagai "Kampus Orang Basudara", yang menurut keterangan rektornya akan memberi pengetahuan untuk semua mahasiswa tanpa memandang agama dan etniknya. Pilihan terhadap tema "Kampus Orang Bersaudara" memberi impresi tentang pentingnya semangat persaudaraan yang terintegrasi dalam proses pembelajaran di kampus tersebut.

Sementara di kalangan Islam terus dihebahkan konsep multikulturalisme, sebagai wacana sosial untuk mengekspresikan semangat persaudaraan. Bahkan Institut Agama Islam Negeri (IAIN) Ambon memasukkan multikulturalisme sebagai visi utama dan tema sentral yang membingkai keseluruhan aktiviti akademik di IAIN Ambon. Multikulturalisme dimasukkan dalam kurikulum akademik semua jurusan, kegiatan kemahasiswaan dan kegiatan akademik lainnya. Sebagai implementasi dari visi multikulturalisme, maka pada tahun 2015, sejumlah mahasiswa dari Jurusan Sosiologi Fakultas Dakwah dan Ushuluddin IAIN Ambon dikirim untuk melakukan latihan praktikal di Gereja Protestan Maluku (GPM). Penempatan di gereja merupakan salah satu terobosan penting yang dilakukan IAIN dalam membangun pengertian dan pengetahuan mahasiswa terhadap keragaman dan perbezaan. Dengan belajar pada perbezaan secara langsung (by experiance) mahasiswa diharapkan memiliki sikap dan karakter yang menghargai perbezaan dan dapat bersikap ramah terhadap kelompok lain yang memiliki keyakinan yang berbeza.

Merujuk. Eck (2002), semangat pluralisme yang sedang dibangun di Ambon dapat mendorong keterlibatan energetik dan aktif dalam menghadapi segregasi dan keragaman. Kesedaran pluraliti akan mendorong dialog-dialog keagamaan yang inklusif untuk saling berbicara dan mendengar, membuka pikiran mengenai kesamaan pemahaman dan realiti perbezaan. Melalui pendedahan tentang pluralisme dan multikulturalisme, berbagai kelompok sosial di Ambon hendak mencari jalan untuk membangun saling pengertian, pemahaman dan kerjasama yang lebih erat. Meskipun secara geografis maupun sosiologis, masyarakat kota Ambon masih tetap berada dalam situasi yang segregatif. Konsep akademik tentang pluralisme dan multikulturalisme diharapkan dapat dimanfaatkan untuk mengelola perbezaan dan keragaman di Maluku. 


\section{Tentangan Integrasi Sosial: Radikalisme Agama dan Pesona Politik Identiti}

Meskipun penulis telah menunjukkan berbagai perkembangan positif tentang integrasi sosial di kota Ambon berserta nilai-nilai baru yang menyertainya, namun masih terdapat potensi konflik yang perlu diwaspadai, terutama berkaitan dengan ancaman radikalisme agama yang terus mencari tempat dalam masyarakat yang berpotensi menjadi konflik. Demikian juga ancaman dari praktik politik identiti yang cenderung menonjolkan fanatisme primordial yang saat ini sedang menjadi gejala umum praksis politik di Indonesia. Jaringan radikalisme yang dimaksud dalam tulisan ini adalah fenomena kelompok keagamaan yang menyebarkan fahaman eksklusif di tengah masyarakat kota Ambon. Fahaman radikal tersebut berasal dari kalangan Muslim ataupun Kristian yang biasanya kurang menyukai praktik kerukunan aktif atau slogan pluralisme dan multikulturalisme yang sedang semarak di Ambon.

Hal ini perlu diingatkan sebab di kalangan Muslim, jaringan radikal masih memiliki akarakar kultural yang terbentuk selama konflik Maluku. Gerakan-gerakan yang pernah dibangun oleh kelompok radikal seperti Lasykar Jihad masih meninggalkan asas kultural yang mewarisi cara pandang keagamaan yang cenderung eksklusif. Kelompok-kelompok ini lahir dari para pejuang yang tidak pulang ke daerah asalnya. Mereka menetap di Ambon dan membangun gerakan dan kelompok keagamaan yang ternyata berbeza dengan gerakan agama yang sudah ada sebelum konflik: Islam moderat. Menurut catatan Badan Nasional Penanggulangan Terorisme (BNPT) gerakan ini menamakan diri sebagai gerakan salafi yang memang tidak dapat dikategorikan sebagai gerakan terorisme, meskipun tidak menutup kemungkinan dalam jangka akan mengarah ke eksklusifme radikal yang keras dan kaku (Laporan BNPT dan Policy Brief. t.th).

Selain radikalisme agama, tentangan lain yang perlu diwaspadai dalam proses integrasi sosial dan perdamaian umat beragama di Ambon adalah fenomena politik identiti. Pada dasarnya ia merupakan bahagian dari upaya etnik, komuniti agama, dan budaya untuk dapat disesuaikan dalam sistem politik tempatan. Namun hal ini mencemaskan bila ditampilkan di Ambon yang secara faktual baru sembuh dari luka konflik. Fenomena politik identiti dapat memunculkan kembali sentimen-sentimen keagamaan dan etnik yang mudah mencetuskan mobilisasi kekerasan.

Era politik Indonesia kontemporari saat ini menunjukkan sebuah realiti kegamangan yang dialami bangsa Indonesia berkaitan politik identiti. Heller (2002) mengandaikan politik identiti sebagai politik yang memfokuskan pembezaan sebagai kategori utamanya yang menjanjikan kebebasan, toleransi, dan kebebasan bermain (free play) walaupun memunculkan pola-pola intoleransi, kekerasan dan pertentangan etnik. Dalam kes Indonesia dan lebih khusus lagi di Maluku godaan politik identiti yang muncul cenderung mengandungi perkauman, agama dan ideologi politik.

Pola operasi politik identiti ini dapat kita jumpai pada realiti yang terjadi di masyarakat ditunjukkan dengan banyaknya perbenturan kepentingan dan fenomena ego sektoral di Ambon, antara lain: Pertama, operasi politik identiti dimainkan peranannya secara optimal melalui roda pemerintahan. Hal ini sejalan dengan tuntutan keseimbangan identiti agama ataupun etnik dalam birokrasi dan sistem politik lokal. Politik identiti ini ditampakkan dengan maraknya isu etnik dan gejala primordialisme yang diusung melalui isu-isu agama dan etnik dalam suasana penting seperti pilkada dan pemilu legislatif. Demikian juga isu etnik asli dan pendatang, yang mengandungi isu majoriti dan minoriti. Kedua, dalam konteks Maluku politik identiti juga memanfaatkan ekspresi-ekpresi keagamaan yang secara tidak langsung mengandungi kecenderungan 'menyingkirkan' kelompok lain yang dianggap minoriti.

Berdasarkan pada kedua pola operasi tersebut, politik identiti nampaknya cenderung mennganggu wawasan keagamaan inklusif yang hendak dibangun di Maluku. Apalagi dalam satu dekad terakhir, upaya meningkatkan peranan politik berbagai kelompok tempatan di kota Ambon terus mengambil setting politik identiti (Tomsa 2008). Pilkada telah menggoda elit dan praktisi politik untuk mengkonsolidasikan kepentingan politik atas nama agama dan etnik yang 
sebetulnya cukup berbahaya bagi proses perdamaian. Sebetulnya menguatnya politik identitas melalui wakil kelompok agama dan etnik dalam menyediakan jawatan di birokrasi sebagaimana yang sedang dipaksakan beberapa kalangan di Ambon, memiliki manfaat jangka pendek untuk mengelak konflik. Namun dalam jangka panjang, hal ini tidaklah kondusif bagi upaya-upaya konstruktif untuk merawat perdamaian yang telah tercipta dalam satu dekad terakhir.

Tulisan ini menunjukkan bahwa meskipun kota Ambon-Maluku masih terbelah dan tersegregasi berdasarkan indentiti keagamaan; Islam ataupun Kristian, tetapi sedang terjadi sebuah proses integrasi sosial yang positif. Berkaitan dengan dinamika tersebut maka tulisan ini merumuskan beberapa point penting sebagai kesimpulan. Pertama, bahawa integrasi sosial di kota Ambon terjadi secara alamiah, mulanya disebabkan desakan keperluan ekonomi yang menyatukan warga pada ruang ekonomi seperti pasar, kemudian berlanjutan pada inisiatif untuk merivitalisasi nilai-nilai kearifan lokal sebagai jambatan penghubung persaudaraan. Masyarakat juga memanfaaatkan acara-acara keagamaan seperti MTQ dan Pesparawi sebagai media integrasi sosial sekaligus meningkatkan kerjasama lintas iman yang semakin positif. Sementara itu, perbezaan kepentingan politik diurai melalui upaya menghidupkan kembali ruang publik seperti pasar, pejabat, sekolah, dan warung kopi yang secara mengejutkan tumbuh subur pasca konfik. Di sisi lain, terjadi penguatan politik keseimbangan yang memberi tempat (representasi) bagi kepentingan agama dan etnik dalam pemberian jawatan politik dan publik di birokrasi dan sistem politik lokal.

Kedua, perkembangan terkini di kota Ambon-Maluku juga telah menunjukkan semakin menguatnya model kerukunan yang aktif yang ditandai dengan proses interaksi sosial antara agama yang semakin aktif, cair dan penuh dialog. Pada saat yang sama para pemegang taruh (stakeholders) seperti organisasi keagamaan, kekuatan-kekuatan civil society serta komuniti perguruan tinggi juga berupaya menyesuaikan konsep-konsep akademik seperti pluralisme dan multikulturalisme untuk memperkuat visi perdamaian di Kota Ambon. Ketiga, tulisan ini juga mengingatkan bahawa meskipun terjadi proses integrasi sosial dan perkembangan perdamaian ke arah yang semakin positif di kota Ambon, namun masyarakat kota Ambon masih harus tetap berwaspada tentang kemunculan fahaman keagaman radikal yang pada tahap tertentu masih ada dalam kehidupan masyarakat; sama ada Muslim ataupun Kristian di Kota Ambon. Pada masa sama pesona politik identiti yang muncul dalam momentum politik lokal seperti Pemilu dan Pilkada juga harus dihadapi dengan hati-hati, sebab secara tidak langsung boleh melahirkan sikap primordial (pandangan yang bepegang teguh terhadap hal-hal yang dibawa sejak kecil mengenai tradisi atau kepercayaan) dan enosentrisme (penilaian terhadap kebudayaan lain atas dasar nilai dan standard budaya sendiri) berbahaya bagi pembangunan perdamaian di masa depan.

\section{References}

Abdullah, Irwan (ed.). 2006. Agama dan Kearifan Lokal dalam Tantangan Global. Yogyakarta: Sekolah Pascasarjana UGM dan Pustaka Pelajar.

Abdullah, Subair.2008. Segregasi Pemukiman Berdasarkan Agama. Yogyakarta; Graha Guru.

Azra, Azumardi. 2000. Muslim and Christian Relation in Contemporary Indonesia. In. Komprensi tentang Christian and Muslim in The Commonwealth England: Windsor.

Blau, Peter M. \& Schwartz, Joseph E. 1984. Crosscutting Social Circles: Testing a Macrostructural Theory of Interrelation. Orlando: Academic Press.

Saidin, Ernas. 2006. Perjanjian Malino dan Penyelesaian Konflik Maluku. Tesis Magister pada Program Pascasarjana Ilmu Politik Universitas Indonesia.

Saidin, Ernas. 2012. Policy of Social Conflict Resolution; Implementation of The Malino Agreement. Journal of Govermant and Politics. 3 (2): 316-344.

Eck,Diana L. 2000. New Religious America; How a Cristian Country has Become The World Most Religiousy Diversy Nation. New York: The Continum Internastional Publishing. 
Latuconsina, Adam. 2013. Relasi Agama dan Etnik dalam Pendidikan. Yogyakarta: Kemenag RITICI Publication.

Nugroho, Heru. 1999. Konstruksi Sara, Kemajemukan dan Demokrasi. UNISIA. No.40 (XXII), IV.

Parekh, Biku. 2008. Rethinking Multiculturalism, Keragaman Budaya dan Teori Politik. Yogyakarta: Kanisius.

Pranawati, Rita (ed.). 2011. Kebebasan Beragama dan Integrasi Sosial. Jakarta: Center for Study of Religion and Culture (CSRC)

Rauf, Maswadi. 2000. Konsensus Politik Sebuah Penjajagan Teoritik. Jakarta: Direktorat Jenderal Pendidikan Tinggi Departemen Pendidikan Nasional.

Ritzer, George \& Goodman, D.J. 1992. Sosiologi Ilmu Pengetahuan Berparadigma Ganda. Jakarta: Rajawali Press.

Ritzer, George \& Goodman, D.J. 2004. Classical Sociological Theory. McGraw-Hill.

Syamsudin, Nazaruddin. 1989. Integrasi Politik di Indonesia. Jakarta: Gramedia

Tomsa, Dirk. 2008. Electoral democracy in devided society; the 2008 gubernatorial election in Maluku. Indonesia. Journal of South East Asia Research. 17 (2): 229-259.

Varshney, Asutosh. 2003. Etnic Conflict and Civic Life: Hindus and Muslims in India. New Haven: Yale University. 